CHAPTER 12

\title{
Towards a new approach to the definition of living heritage sites
}

\section{Continuity (criteria)}

It was shown that continuity is the key concept for the definition of a living heritage site; yet, there are cases in which continuity may not be linked to an actual site or may be undermined by the association of other communities to a site (Part 1). In an attempt to link continuity with the site and prioritise it over the other communities' associations with and uses of the site, the following set of criteria should be offered, which are inextricably linked to each other (figure 48):

a) Primarily, the continuity of the heritage site's original function - the purpose for which the heritage site was originally intended. Function is seen as the root of a living heritage site. In the Orthodox Church, as demonstrated in the case of Meteora, heritage is rooted in the Tradition and is a purely functional one: it acquires its existence and meaning exclusively within the conduct of the worship of God (the Holy Liturgy), as followed and continually developed over time by the monastic communities of the site. In a similar context, in Buddhism, continuity is considered to be rooted in the context of religion itself and then applied in the context of heritage. The Buddha, Dhamma [the teachings of Buddha] and Sangha [the order of monks of Buddha], known as the Triple Gems, constitute the core of Buddhist religion, and are still living. Buddhist heritage supported the Buddhist religion throughout its history, and is still living (Wijesuriya 2005, 30-33). In this context, a cetiya/stupa - a permanent structure of Buddhist monasteries built to enshrine relics - should 'be seen only in its full functional state and convey the symbolic meaning it represents' (Rahula 1956, 284). In a similar example, in Hinduism continuity is also seen as rooted in religion and particularly in the continuity of the conduct of religious rituals still performed on the sites in accordance with the 'Agamas' (i.e. a codified set of rules governing the practice of religion and ritual as well as the operation and the construction of Hindu Temples) (Archaeological Survey of India 2003, 262 and 8). In another example, the Kasubi tombs in Uganda (a World Heritage Site) have retained over time their function as burial places for the Buganda Kings (Kigongo 2005, 34-36; Ndoro 2004, 84; Munjeri 2004b, 77-78).

b) The continuity of the community's connection with the heritage site. There is a specific community group that created the living heritage site and sustains the original function of the site, retains its original connection with the site over time and still considers the site an integral part of its contemporary life in terms of its identity, pride, self-esteem, structure and well-being, 


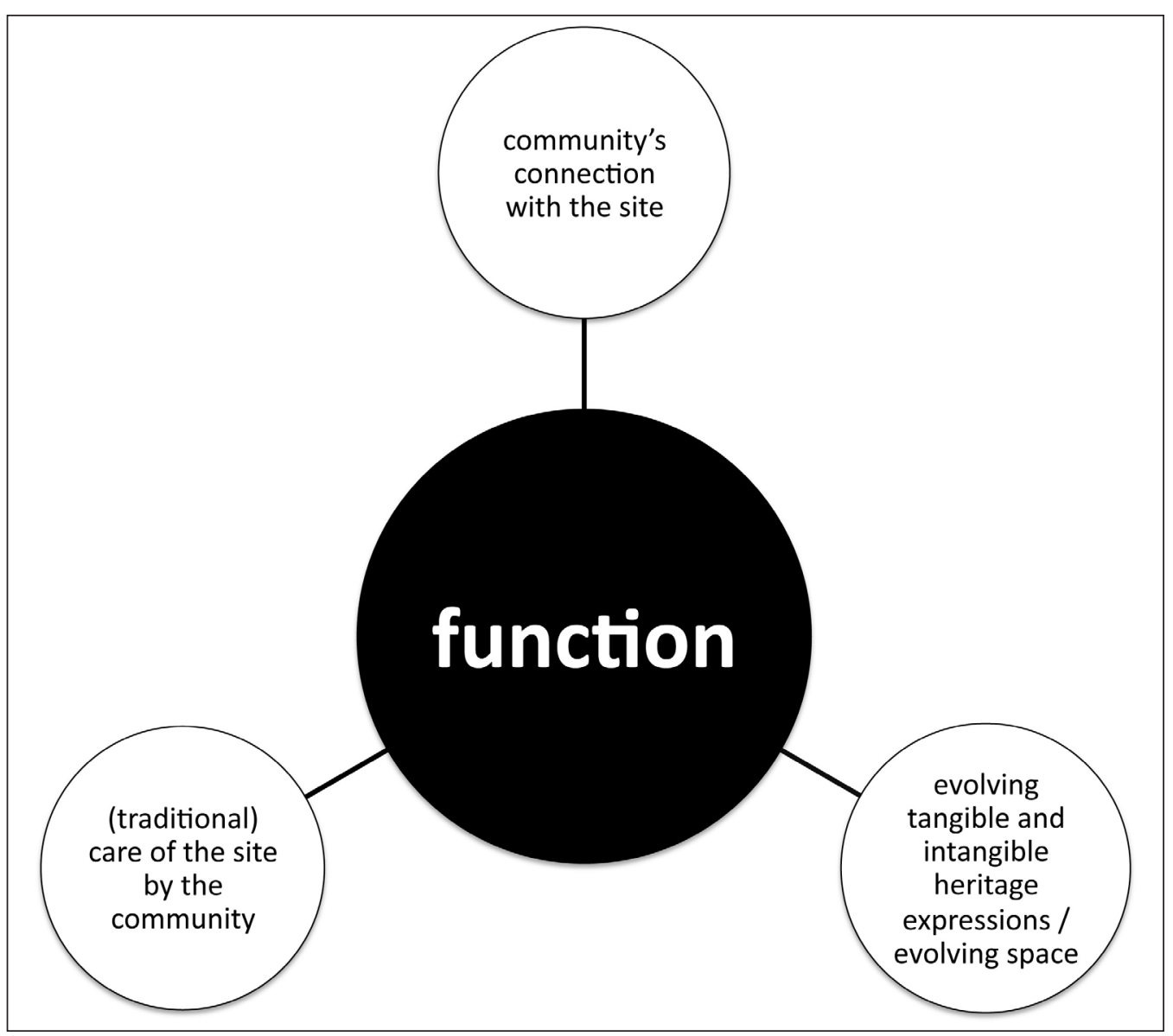

Figure 48: The criteria of continuity.

has a strong sense of ownership/custodianship for the site and sees the caring for the site as its own inherent obligation (see Poulios 2011; Wijesuriya 2005, 30 and 37; Chapagain 2013; Sharma 2013). This community, referred to as 'core community', is seen as an inseparable part of the living heritage site, and is thus clearly differentiated from the other community groups involved in the life of the site, often referred to as the 'broader community' (or 'peripheral communities'). At Meteora, it is the monastic communities that sustain the function, define and create space, and take care of the site. The monastic communities cannot define themselves detached from the site, considering it their only home on earth and their only path that would lead them - through the unification with Christ - to their true, eternal home Paradise). In New Zealand, the indigenous heritage of tangata whenua relates to whanau, hapu, and iwi communities:

It shapes identity and enhances well-being, and it has particular cultural meanings and values for the present, and associations with those who have gone before. Indigenous cultural heritage brings with it responsibilities of guardianship and the practical application and passing on of associated knowledge, traditional skills, and practices. (ICOMOS New Zealand 2010, article 3)

c) The continuity of the care of the heritage site by the community, as expressed through community's management (and ownership) mechanisms and maintenance practices. These mechanisms 
and practices are traditional (or established over time), i.e. based on skills, materials and techniques that existed before the formation of the modern scientific-based principles and practices of conservation.

Traditional management mechanisms consist of a series of community norms to promote the safeguarding of a site including sacred and pragmatic controls, customary laws, traditions, taboos, myths and rites (Edroma 2001, 55-56; see also Joffroy 2005, 2-4; Ndoro 2004, 81). Traditional management mechanisms at the site of Meteora constitute the typicon, the Holy Assembly, and the Abbot of each monastery. The typicon, as noted above, is not a static document but is learnt in practice with the conduct of worship on an everyday basis, and is thus evolving in accordance with the changing needs of the monastic community over time. In another example, traditional management mechanisms at the site of Kasubi, Uganda (a World Heritage Site) are: the royal tombs are shielded behind bark-cloth curtains and access is limited to the spiritual guardian (Nalinga) and the prime minister of the Buganda Kingdom (Katikkiro), people are not allowed to turn their back inside the main tomb (Azaala-Mpanga) and shoes are removed as a sign of respect (Munjeri 2004b, 77; Kigongo 2005, 31 and 34-36).

These management mechanisms are often documented, i.e. they are based on, and guided by, texts. An example of such a text, in Orthodox monastic sites such as Meteora, is the typicon. Other examples of such texts are Mayamatha for Buddhist temples and Agamas and Vedas for Hindu temples (see Wijesuriya 2000, 102; Wijesuriya 2005, 34-37; Archaeological Survey of India 2003, 262-263; Champakalakshmi 2001, 18-20). There are cases, however, in which these mechanisms are not based on written sources but have passed down through generations, as in the case of a large part of the Orthodox Tradition including the rituals for the conduct of the Holy Liturgy.

With regards to the traditional maintenance practices, though the material is generally preserved, these practices may have completely different and even contradictory implications for the material of the sites. Examples of such practices, which show a wide range of implications for the material, are the following:

- Partial replacement of existing material with same material. This practice takes place irregularly, when and where repairs are needed. This process is mostly applied in structures made of fragile, normally organic, materials, often in hostile climates. The continual renewal of the individual architectural parts of the Meteora monasteries, incorporated in harmony within the architectural type of the monasteries, is an example of such a practice. Other examples: Wooden Shinto, Buddhist and even contemporary buildings in Japan (Larsen 1988; Larsen and Ito 1990; Inaba 2005, 51-52; Pressouyre 1996, 12); Kasubi tombs in Uganda (Kigongo 2005, 34-36; Ndoro 2004, 84; Munjeri 2004b, 77-78); the Great Mosques of Timbuktu in Mali (Ould Sidi and Joffroy 2005, 23-25); mud houses in Northern Ghana and Southern Burkina Faso decorated by groups of Nankani women (Kwami and Taxil 2005, 75-79); and Buddhist and Hindu temples (Wijesuriya 2005, 34; Archaeological Survey of India 2003, 262-263).

- Partial renewal of existing material with different material. This practice is applied mostly in cases where the replacement material is stronger and longer-lasting, less expensive and/ or easier to find than the existing one. This practice often serves broader social, economic or religious purposes as well (see Joffroy 2005, 3-4). Examples: The tribes of Bambara, Senufo and Bozo in Mali replace the mud roofs of their houses with ones made of corrugated iron (pers. comm. Renata Anna Walicka-Zeh); in the sacred forest of Bamezoume in Benin local people replace wooden parts of statues with others made of metal car (and other) parts.

- Total physical renewal. This practice serves primarily symbolic, ritual reasons (rather than practical reasons related to the decay of the existing material, as in the case of partial replacement of existing material with same material: see above). Examples: 'Shikinen 
Zotai' is a Shinto ritual in Japan that requires renewing of the shrine buildings of the entire precinct every twenty years, dating back to the seventh century (Inaba 2005, 51-54; Inaba 1995, 331-332; Ito 1995, 44); the main façade of the Temple of Arou is roughcast with clay, during the annual feast of Bulo in the Dogon country in Mali (Cisse 2005, 90-94); in Nagaland, India, houses with central post are reconstructed in their entire precinct every twelve years, as part of a local tribal tradition (pers. comm. Ranesh Ray); the repainting of rock art images as a way of renewing the spiritual power of the images the repainting of rock art images as a way of renewing the spiritual power of the images (see Walderhaug Saetersdal 2000, 163-180), as with Wandjina rock images in the Kimberley area in Australia (Mowaljarlai et al. 1988; Mowaljarlai and Peck 1987; Bowdler 1988, 517-523).

- Immersion of physical material. This practice is in most of the cases part of a ritual ceremony. Examples: immersion of (ritual) objects as part of rituals of Zuni Ahayuda, New Mexico (Edmund Ladd, 1992, quoted in Sease 1998, 106); immersion of clay, plaster and wax (ritual) objects as part of Hindu rituals in India: during Durga Dussehra-Durga Puja Festival, Ganesh Chaturthi Festival in Maharash, Samachakeva Festival in Bihar State, and Rath Jatra Festival (Berkson 1995, 215-219; pers. comm. Ranesh Ray).

- Replacement of the entire structure with a new one. Examples: In Buddhism and Hinduism the belief is that a statue, if broken, loses its sacredness and is thus to be replaced not partially but as a whole. This practice is illustrated in the case of the Buddhist statue of Ta Reach at Angkor Wat in Cambodia as part of the folk religion known as 'Nakta' (Shimotsuma, Stovel and Warrack 2003, 16) and in the case of the Temple of the Tooth Relic in Sri Lanka (see Part 1; Wijesuriya 2000).

Behind these differing approaches towards the fabric there appears to be a common underlying philosophy. These practices demonstrate that the physical, material structure may be given a low priority. Emphasis is not considered to lie in the material and in elements of materiality of sites and objects, such as: the age of a structure, the type of material, and the structure itself. Emphasis is on the non-physical elements of sites and objects: the sites' and objects' wider cultural significance and conceptual integrity. Thus, sites and objects are 'often described culturally, in terms of "process" rather than "product" ' (Clavir 2002, 245; see also Ward 1992, 33-37; Mowaljarlai et al. 1988). Changes in the fabric are an inseparable part of this process, and are thus an essential requirement for the survival and continuation of a living heritage site.

It should be stressed that the application of practices in which the physical, material structure may be given a low priority does not mean that the core community does not care about the material. The core community cares about the material, but this caring is placed in a broad context and scope, that of the continuity of community's connection with heritage. Jones made the following remark:

the materiality of artifacts and monuments is implicated in, indeed lives at the heart of, their biographies: things are born, they grow, breathe, live and die; they are conceived as having a soul and a personality, and as being nourished and harmed by other substances such as air, soil and water. $(2006,122)$

d) The continual process of evolving tangible and intangible heritage expressions of a site / of the evolving space of a site (tangible and intangible heritage expressions are seen as interlinked, comprising a unified space). The space is evolving yet within the traditional parameters as defined by continuity and in accordance with the original function of the sites. In this sense, the evolution of the space is embraced as a part of the continuity, and is seen as an essential requirement for the maintenance of a living heritage site over time to the present. As it was shown, the art of the Orthodox Church in all its expressions (such as architecture, sculpture, painting, poetry, and 
music) is continually evolving, always within the Orthodox Tradition centred on the worship of God. In this context, the space of the Meteora monasteries (including: the forms of monastic space, the external space of the monastery, the internal space of the monastery and the route within the monastery) is continually evolving, always within the Orthodox Tradition centred on the worship of God. Other examples: In Hinduism, the temples maintain over time a close relationship with their surrounding urban settlement in terms of spatial arrangement, with the temple forming the centre around which the surrounding settlement is developed - thus called 'temple town' (Archaeological Survey of India 2003, 21-27 and 262-264). In Sri Lanka, several temples were built over the course of time for the housing of the Tooth Relic of Buddha, with the latest/current one being the so-called Temple of the Tooth Relic in the World Heritage city of Kandy (Wijesuriya 2000). In Benin, temples constructed for the conduct of voodoo rituals have shifted several times depending on circumstances such as the appointment of a new priest for the conduct of the rituals (Munjeri 2001, 17-18; Munjeri 2004a, 15-16). In Kokologo in Burkina Faso, the Kings traditionally have a new palace built after the former King dies (pers. com. Sophie Hsu Ming).

\section{The way continuity has evolved over time to present}

Continuity, as discussed above (consisting of all four elements), continually evolves over time to the present, in response to the changing political, economic, historic and social circumstances at a local, national and international level.

At Meteora, continuity (i.e. the Orthodox Tradition as followed by the monastic communities of the site) was affected by a series of major factors. First, in the 1940s and the 1950s, continuity at Meteora was affected by the outbreak of World War II and the Civil War as follows:

a) Concerning the continuity of the heritage site's original function: severe restriction and even cease of the monastic function of the majority of the monasteries, and in some cases the operation of guesthouses inside the monasteries.

b) Concerning the continuity of the community's connection with the heritage site: abandonment of the monasteries, and consequently break of the temporal continuity of the monastic communities. As a consequence, the new monastic communities, i.e. those reestablished on the site in the 1960s, did not have the experience of the site, and were not aware of the specific needs of monastic life on the site.

c) Concerning the continuity of community's care for the heritage site: neglect for the conservation and management of the monasteries.

d) Concerning the process of evolving tangible and intangible heritage expressions / of the evolving space of the site: collapsing of monasteries, and thefts occurring in the monasteries.

Second, after the 1960s, upon the re-establishment of the monastic communities on the site, continuity at Meteora was affected by two other factors: the philanthropic-missionary approach to monasticism (i.e. a different approach to monasticism that was not strictly within the Orthodox Tradition, and was brought from abroad through the 'ecclesiastical organisations'); and the growth of the tourism and heritage industries. These two factors became interlinked to each other: the Meteora monastic communities accepted the growth of the tourism and heritage industries in the context of their philanthropic-missionary approach to monasticism. The two factors affected continuity as follows (it should be noted that the impact varied among the monasteries, depending on the different attitude of each monastic community towards heritage and tourism industries based on their differing degree of commitment to the philanthropic-missionary approach): 
a) Concerning the continuity of the site's original function. Meteora is no longer used exclusively as a monastic site, but has increasingly become a heritage site and a tourist attraction as well. As a result, the following problems in the operation and management of the site appeared: separation between monasticism and tourism, increased emphasis on tourism, and increasing adjustment of monastic life to the pressure of tourism.

b) Concerning the continuity of the community's connection with the site. The introduction of the philanthropic-missionary approach to the site, on the one hand, affected the way the monastic communities see monasticism, Meteora and their relationship with the outside world: Meteora is no longer considered simply a place for the worship of God, but also a place for the conduct of philanthropic-missionary activity for the benefit of the wider society. In this sense, the conduct of philanthropic-missionary activity is considered the most significant contribution as well as responsibility of the monastic community towards the wider society and, therefore, the entire operation and management of the site has to be incorporated within it. The growth of tourism and heritage industries, on the other hand, affected the way the outside world sees Meteora and its relationship with the monastic communities: Meteora is no longer seen simply as a monastic site, but mainly as a tourist attraction and a place of heritage significance. The combined influence of these two factors affected the site in various ways: The monastic communities see their site's position in the tourism industry as a means to accumulate increased power and promote the Orthodox faith to the visitors. Also, the monastic communities, due to the presence of the visitors, feel increasingly restricted within their site, find it difficult to conduct the worship of God, are hindered from communicating with the visitors, and some members of them are eventually made to leave the site; while in other cases the monastic communities feel the need to increase in size mostly in an attempt to deal with the increasing pressure of tourism.

c) On the continuity of community's care of the heritage site (as expressed through community's management mechanisms and maintenance practices). This is illustrated in the inactivity of the Assembly, due to the conflicting views of the Meteora monastic communities on the character and operation of the site.

d) On the process of evolving tangible and intangible heritage expressions / of the evolving space of the site. At Meteora, the monastic communities become increasingly restricted within their space, find it difficult to conduct their worship of God in the existing space and subsequently feel the need to create new spaces through the construction of further buildings. As a consequence, the external and the internal space of the monasteries (as defined by the Tradition of the Orthodox Church) change, while existing buildings are unavoidably replaced in terms of function, and hence the monasteries demonstrate a variety of continually changing spatial arrangements with buildings of interwoven and conflicting functions. An example of an intangible heritage expression that has been affected by the monastic communities' acceptance of the tourism industry is the practice of the striking of the simantron in the Roussanou monastery at the request of the visitors.

In other Byzantine heritage sites in Greece that are still in use (also inscribed on the World Heritage List), continuity has evolved over time in different ways. For example, Mystras was a major Byzantine city that gradually fell in decline and eventually in the fifteenth century ceased to exist as a result of the Ottoman conquest. In 1921, Mystras was declared a national heritage site, and the few local people still residing in the site were gradually removed, their residences were demolished and the site was fenced off. Pantanassa Monastery, located on the site, ceased to function in 1770 until the second half of the nineteenth century, when members of the local community formed a small monastic community. This monastic community has remained to present, rendering Pantanassa 'a living monastery within a necropolis' (Poulios 2010c) (figures 49 and 50). The regulations for the operation of the site as a heritage site and also as a tourist destination 


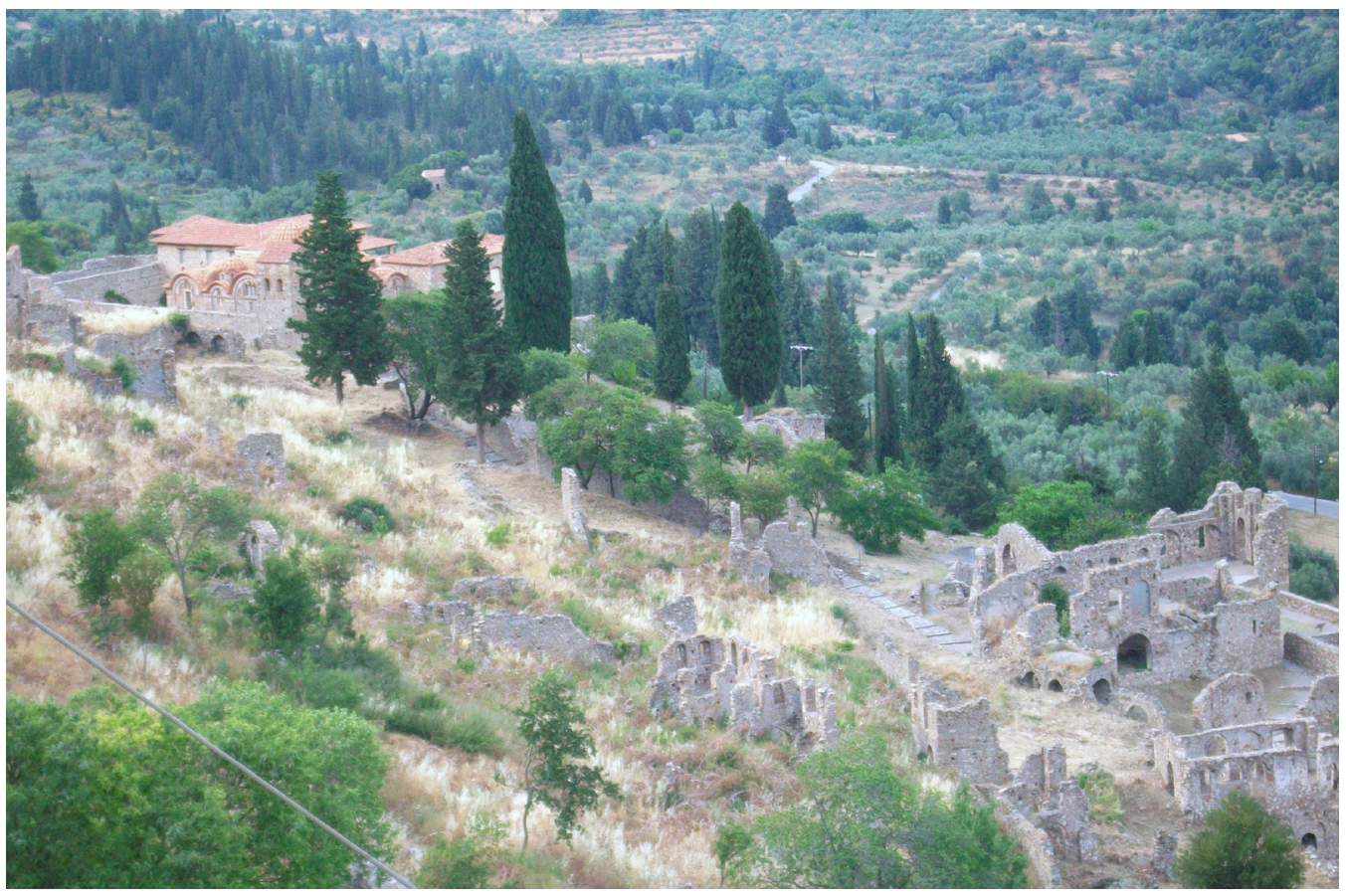

Figure 49: Mystras, Greece: an external view of the site (source: author's photo). The Pantanassa Monastery (on the left) could be regarded as 'a living monastery within a necropolis'.

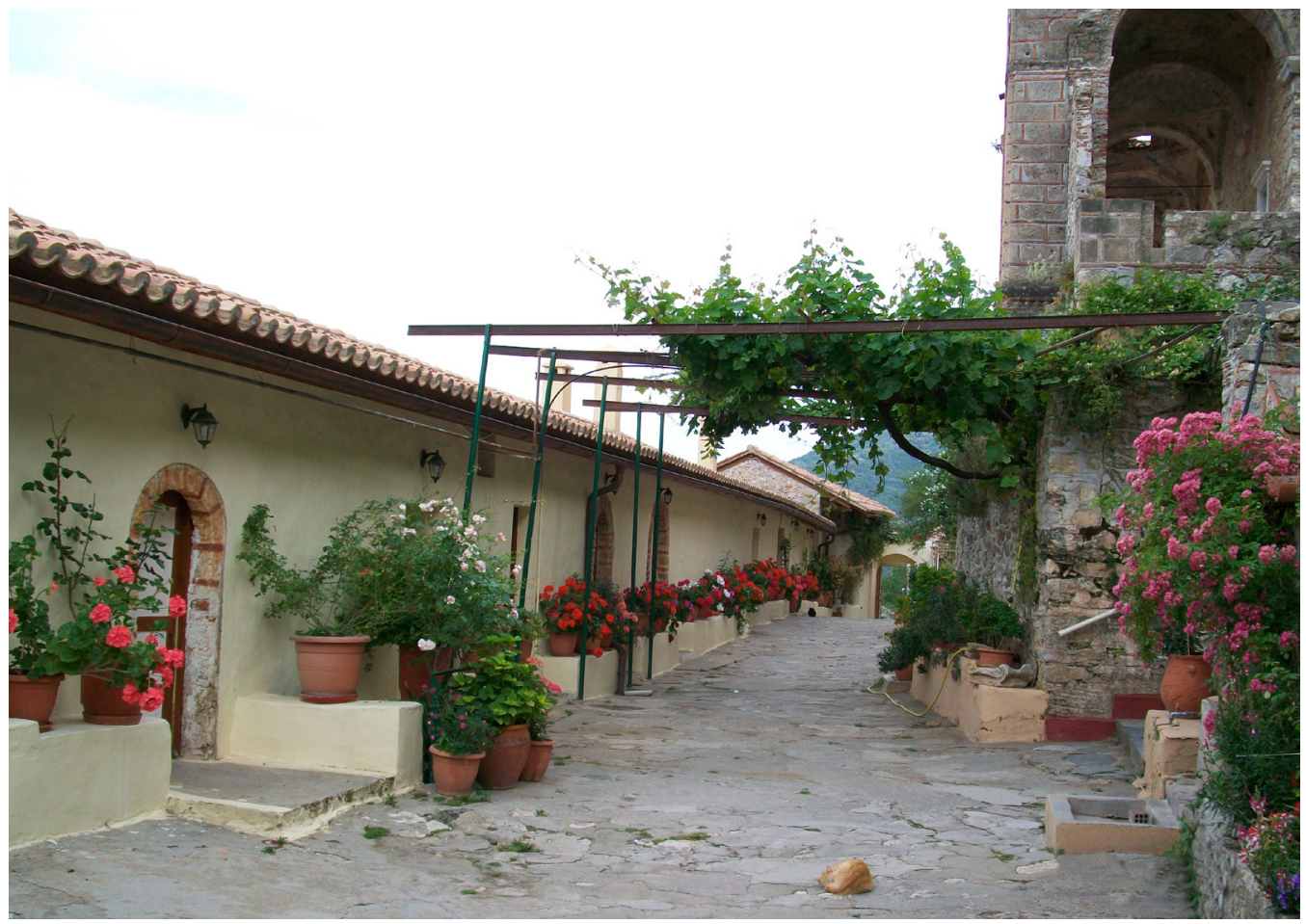

Figure 50: Pantanassa Monastery: a detail of the yard and the cells (source: author's photo). 


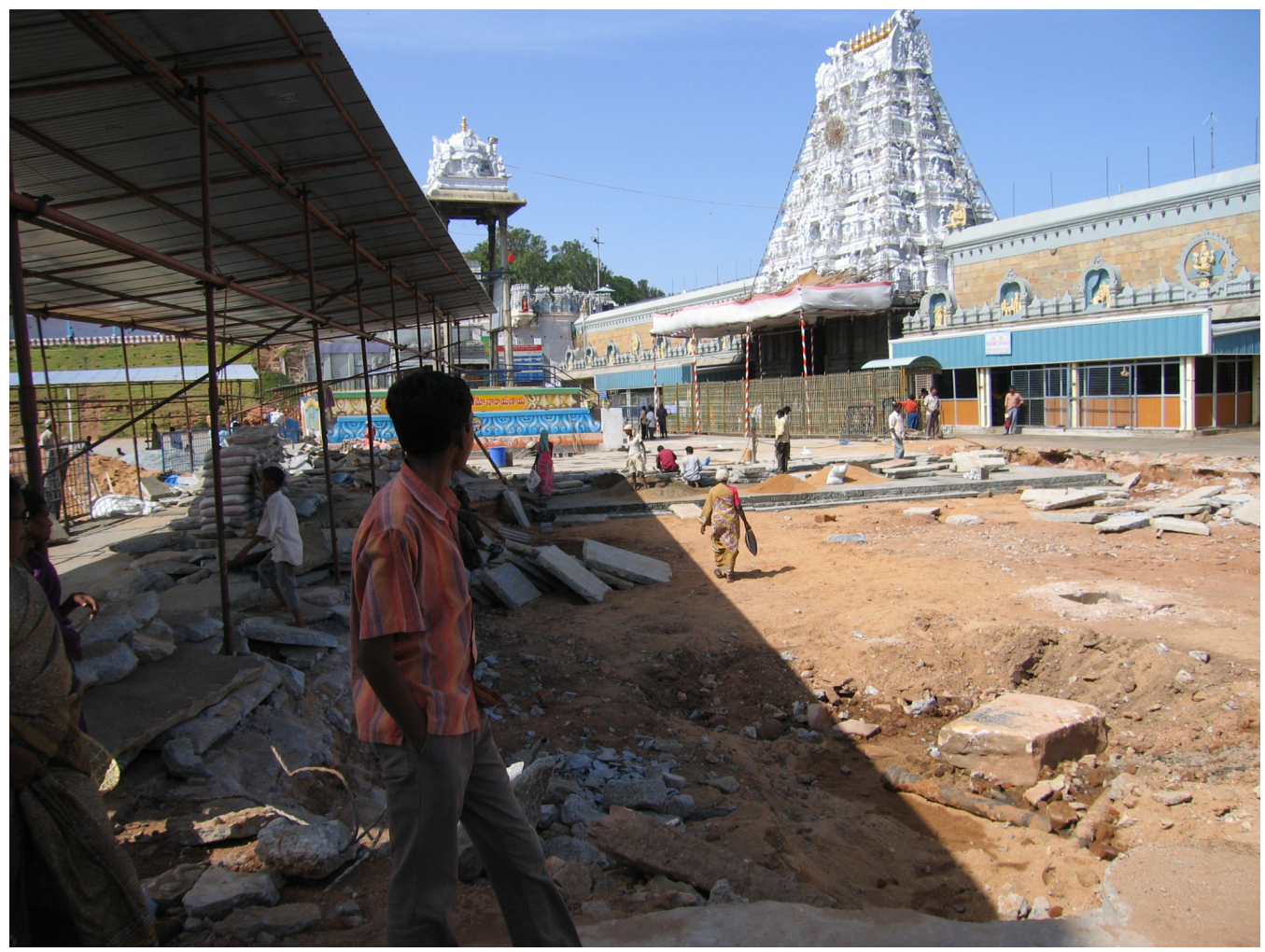

Figure 51: Tirupati Temple, India. Extensive construction activity takes place in the Temple.

are defined by the State / the Ministry of Culture, and the monastic community adjusts its life accordingly (Poulios 2010c; Poulios forthcoming). In another example, the monastic complex of Mount Athos has been in use and has retained its ritual activities as well as its official, legal administrative and management status as a relatively independent region from the outside world from the tenth century throughout Byzantine and Ottoman period up to present day. Mount Athos is an exceptional case in terms of its official, legal administrative and management status: it is legally recognised, on the basis of its traditional law, as a semi-independent region within the state of Greece, with the monastic communities having the administrative and management control through their own official body (the Assembly of the Holy Monasteries of Mount Athos). The site is open to visitors with considerable restrictions: the avaton (i.e. the exclusion of women from entering a monastic site) still continues, and still the number of visitors allowed into the site per day is limited to a specific number. The power of the monastic communities at local, state and even international level pose significant challenges to the protection of the original fabric of the site by the State / the Ministry of Culture (Chatzigogas 2005).

The way continuity has evolved over time has been also examined in the cases of the Hindu Temples of Tanjore, Srirangam and Tirupati in India (Poulios 2010b; Poulios 2011; Poulios 2008). Specifically, the Tanjore Temple, on the one hand, where the religious tradition has been suppressed over time, operates today under the responsibility of the Government of India (through the Archaeological Survey of India), with reference to the modern scientific-based principles and practices and with an emphasis on the preservation of its original space and fabric. The Srirangam Temple and the Tirupati Temple, on the other hand, where the religious tradition has been maintained and even enhanced over time, are managed mostly by the local community and by the 
Temple Board accordingly. The power of the communities creates several complexities to the management of the sites by the heritage authorities, with implications for the original condition of the space and fabric of the sites (figure 51).

In the case of the Temple of the Tooth Relic in Kandy in Sri Lanka (a World Heritage Site), continuity has been maintained and even enhanced over the course of time under the constant support from the royal families and the governors of the country. The monastic community of the site retains its most significant, legally established, power in the operation and management of the site, beyond the control of the heritage authorities. The site remains a most significant religious and pilgrimage centre, and, clearly at a secondary level, a heritage site of national and international significance. The spatial arrangement and the fabric of the site are continually changing in accordance with the original function of the site (see Part 1). 